\title{
An Allegory Of Good And Bad City Government A Comparison of Gothic Siena and Modern Los Angeles
}

\author{
KAREN FIGURA LANGE and SANDRA DAVIS LAKEMAN \\ California Polytechnic State University \\ USA
}

\section{INTRODUCTION}

As our American cities struggle with the problems of growth and development, the human initiated disasters of crime and violence threaten the very existence of the urban core of most large cities. Los Angeles dominates the American crime scene with its gangs and drug dealers, where violent crime will strike one in every three Angelenos in their lifetime. The city is a leading example of environmental disintegration preceding rampant crime. In fact, environmental decay, drug use and crime continue to rise apparently in collaboration with each other. Additionally, the social service organizations are overwhelmed by the influx of immigrants, teenage pregnancy, and AIDS.

Concurrently, the beauty of the natural Los Angeles basin has been lost through massive and capriciously careless over development. Planning and building controls have not preserved the natural environment or assured a visual environment of quality. As Los Angeles copes with the problems of its growth, the community could attempt to confront these environmental challenges by giving the inhabitants of Los Angeles valid reasons for civic pride. Instead of seeking the unusual and the most outlandish, the built environment with proper direction and inspiration could begin to approach the beauty of the natural world that it has replaced.

As the historic example, Siena demonstrates that beauty and long-term economic investment should be linked with quality construction and its subsequent conservation. This philosophy can promote civic responsibility, ultimately developing into civic pride. Examples of decisions deliberately made for the benefit of citizens can provide a much needed model for architects, city planners, politicians, and the voting public throughout the country. Certainly to nurture more of a sense of civic pride in the citizens of the American city would help to counter gigantic social problems as we appear to have lost the societ simultaneously with the loss of the environment. Our urban initiative, composed of architecture and public space should inspire good citizenship through physical illustration of the American societal ethos, morals, ethics, and ideals, in a sense, the vita civile for and by the constituents. The theoreticians, designers, con- structors, and citizens must begin to understand that "a beautiful city, a city of deep culture and a prosperous city are interdependent."

This is a proposal then to look to the culturally, and environmentally-rich, historic city of Siena for inspiration and direction; not to mimic, but to search for choices and clues, principles that can be applied to Los Angeles and other troubled American cities looking for their roots and their organic souls. For instance, an ideal example for analysis is the attachment that Italians share with their fellow citizens and cities, calling themselves, Sienese, Milanese, Florentine, Venetian, never Italian. This phenomenon is deeply rooted in the European culture and in Italy, it is termed, "campanilismo --- the attachment to one's own churchtower," hence town. It "has remained one of the primary human experiences" and is evident today in literally all Italian towns. ${ }^{2}$

\section{THE COMPARISONS: HISTORY AND BACKGROUND}

Leonardo Benevolo, in The History of the City, states that it is important to study the cities that have a "continuing link" between the Middle Ages and the present day. He writes, "What should be studied is not a dead city but a city that has partly survived within a modern urban complex." Furthermore, "a living city such as Siena . . . cannot be cleared by archaeologists to make way for scientific research ....We, therefore, have to make use of more restricted and less certain documentation, but this can be compensated for by direct experience; for example, it is possible to walk through the Piazza del Campo in Siena ... down the streets of Perugia ... and meet the descendants of the medieval inhabitants, who sometimes still live in the same houses and work in the same workshops as their ancestors." It is compelling then to compare the aesthetic, cultural, political, societal, and architectural manifestations of Gothic Siena, with the most modern metropolis of our time, Los Angeles.

In the Medieval Ages, the word citt inferred endeavors to form "a just human society and the role of citizenship was not grudgingly undertaken as a duty but welcomed as a high 
function." Throughout the commune, in fact, the city fathers chose to embellish civic projects in a didactic manner with symbolic reminders of collective social beliefs. Given that a very small percentage of the population was literate, Cardinal and Theological virtues sculpted in stone and rendered in fresco, on view in the public open spaces and within the town hall, provided constant reminders to citizens and politicians alike to instruct and remind them of the goals of good government. Prior to the printing press, only Art and Architecture, expressed and recorded the social history of society. In fact, the origins of memory and the invention of culture are found in Art and Architecture, as "Architecture is the resistance to forgetfulness." 5 Furthermore, John Ruskin professed, that "there are but two strong conquerors of the forgetfulness of humans, Poetry and Architecture, and the latter in some sort includes the former and is mightier in its reality." 6

The Siena and Los Angeles countryside's were inhabited by native peoples over a thousand years ago. Etruscan remains have been excavated in Siena and the city is entrenched with its fortified walls extruded from the ancestral hills upon which it majestically stands today. "Siena came into existence by an alliance of groups or tribes, each occupying a different hill or fortress." " Situated in three castles, the first Sienese claimed the land for the safety of its location; high enough for fortification and visibility, and avoidance of the pestilence caused by mosquito infested lowlands.

Los Angeles bears little resemblance to its original Spanish pueblo beginnings dating from 1781. A prophetic diary entry by Father Juan Crespi in 1769, in fact, had proclaimed the future metropolis of Los Angeles, "We entered a very spacious valley, well grown with cottonwoods and alders, among which ran a beautiful river from the north-northwest .... It has all the requisites for a large settlement ..."

\section{THE COMPARISONS: CITY LAYOUT}

Where Siena's origins are shrouded in myths of wolves and martyred saints, the oldest building left standing in Los Angeles was built in 1781, with the settlement becoming a major city only in the past sixty years. Covering over four hundred and fifty-one square miles, consisting of "eighteen village cores, one hundred and thirty-two incorporated cities and thirteen major ethnic groups," the metropolitan area provides homes for over 14,531,529 Angelenos. ${ }^{10}$ This phenomenal exponential growth has lead to problems of definition and urbanization unparalleled in history and certainly beyond the task of the decision makers in Siena.

Los Angeles was located for its beauty, potential of Christian conversions, and the prime agricultural land along the Porciuncula River. The settlement was situated away from the harbor and the piracy of the oceans and harbors and following the rules of Spanish colonial code. Similar to Siena, it was located away from the pestilence of the wetlands. The agricultural lands and apparently stable cli-

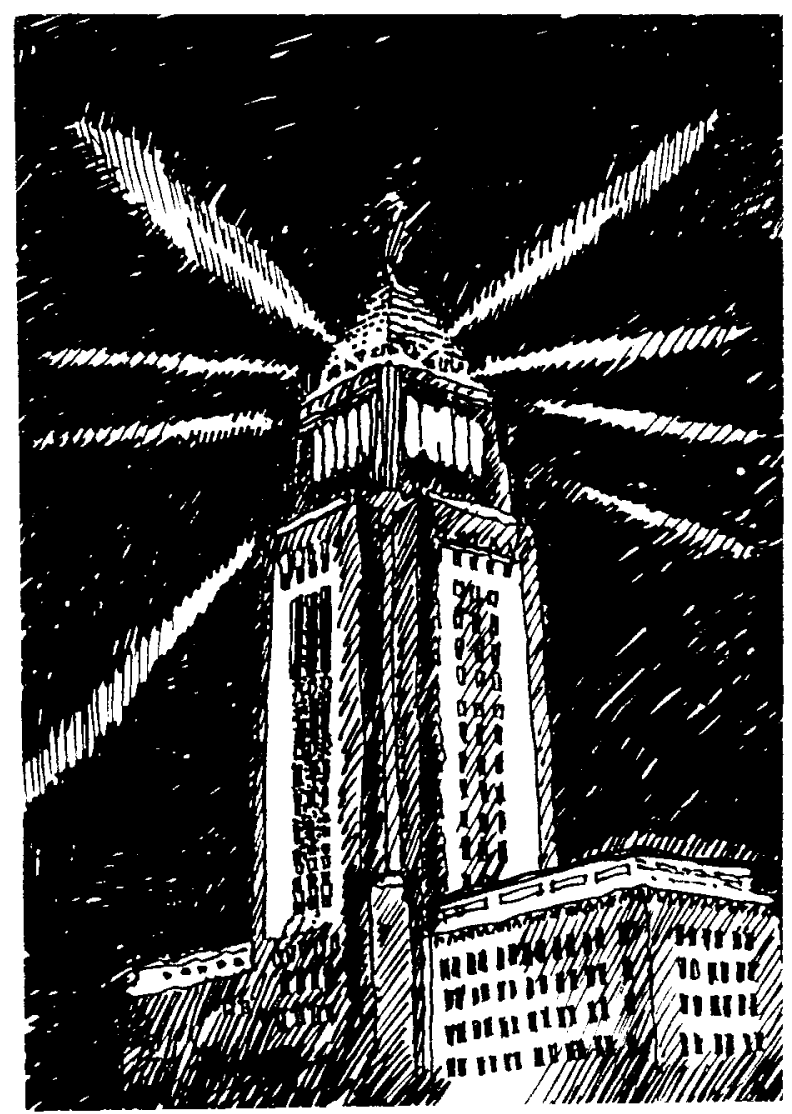

Fig. 1. Los Angeles City Hall, 1928.

mate held little predictions for the future of the settlement. "Unlike most cities in the world, Los Angeles did not develop concentrically. This was due to the pueblo's proximity to the river at its east (and the continued desire for adjacency to the rich agricultural lands on either side of it) and the hills to the west." derived boundaries established in the Spanish ranchos, the city was skewed linearly; original colonial grid versus the irregular patterns of nature. Today the remains of the early organic environment are now expressed in the collision of street grid against diagonal boulevards, all that is left of the boundaries of the Spanish ranchos. The city's control of the limited water resources was used to force outlying communities to face annexation or to merge with Los Angeles. "In the process, highly productive orchards, citrus groves and produce fields had to make way for unplanned and often jerry-built subdivisions, and much of the beauty and charm of the region was lost or impaired." 12

The meandering streets of Siena are a gift from Medieval times and relate to the natural curves of the hills. Lewis Mumford attributes these curves to "mere tracings of the cowpath"13 and "the natural line of a footwalker."14 Earlier Roman theoretician Leone Battista Alberti, offered credence in an aesthetical judgment when he justified the continuously curving street, with its gently blocked yet ever-changing vistas, as advantageous for increasing the greatness of the town, its beauty and convenience for some sun and gentle 
breezes, and to cause confusion to any enemies. ${ }^{15}$ Contemporary Sienese Architect, Andrea Brogi, theorized about the curved streets being the remains of the curved walls of the three early settlements which were then joined together in one city form. ${ }^{16}$

In 1287 , in sympathy with the Tuscan Guelph alliance, the ruling magistracy of twenty-four was reduced to 'nine,' and "a restricted oligarchy, from which the nobility, the judges and the notaries were specifically excluded," began "two generations of stable, prosperous, and peaceful government in which the city reached its highest peak of civic development."' "The 'Nove' emphasized the significance of the Campo by further encouraging the process by which all the streets of the city tended to converge on it." 18 Furthermore, making aesthetic decisions, the city fathers determined that all architectural facades around the Campo would have Gothic tripartite windows devoid of balconies. In the twentieth century, Siena led the world's major cities in making the centro storico a walking area for pedestrians. Today, only lost tourists, delivery trucks at prescribed hours, and emergency vehicles break this code of urban conduct.

The narrow streets and small scale of the city contributes to an all pedestrian center with buses on the fringe and trains on the edge. Perhaps a key design strategy is the fact that all parts of the city are accessible within a thirty minute walk supporting a beneficial health habit for city dwellers. In the 1990's, Siena once again has been forced to confront the effects of the automobile. In the new Bernardo Secchi Masterplan for the Comune di Siena, the major concern has been the impact of the automobile on the city. The greatest difficulty has been to minimize traffic flow through the fringe streets within and near the walls, while enabling access to various parts of the city without touching the centralized 'pedestrian only' area. The second difficulty has been the problem of the storage of massive amounts of cars. Small 'green' areas covering underground parking have been formed away from the center, and away from view in and outside of the city.

In contrast, the metropolitan city plan of today's Los Angeles was not formulated until the advent of technology in the twentieth century and it is the result of the automobile, the railroad, the engineered viaduct, the oil well and the aerospace industry. ${ }^{19}$ Since 1920 , more than in any other city, the car has created the urban plan of Los Angeles. A triangulated grid of freeways and boulevards, the transportation system of Los Angeles is based on time. As the cars rush to the center of Los Angeles their approach celebrates the center of the city which bristles with high-rise structures, a solid mass on a flat plane. Siena, on the other hand has at its center an opening/void, the distinctive Piazza del Campo. Towers and tall palazzi surround the piazza, but the Campo / void is the heart and soul of the community, where time is marked by the shadow of Torre del Mangia, "the giant citysized sundial."20 "Marking time and place is a means of fulfilling architecture's most noble purpose; that is the establishment of the identity of a society through [its] constructed and natural surroundings."

Los Angeles needs to concern itself with many things, but in the center city a pedestrian core would bring human scale back to its inhabitants, and a 'sense of place.' The grid is superimposed over the irregularity of naturally occurring boundaries, colliding to mark order through skewed intersections providing reference and orientation as do landmarks in Siena. "The current need to rebuild Downtown Los Angeles is not based on a romantic notion that the ... city of the past should be reconstructed. Instead, the struggle to redefine the centre of this metropolis is emblematic of the need to direct our society's energies toward a commitment to permanence of place." 22

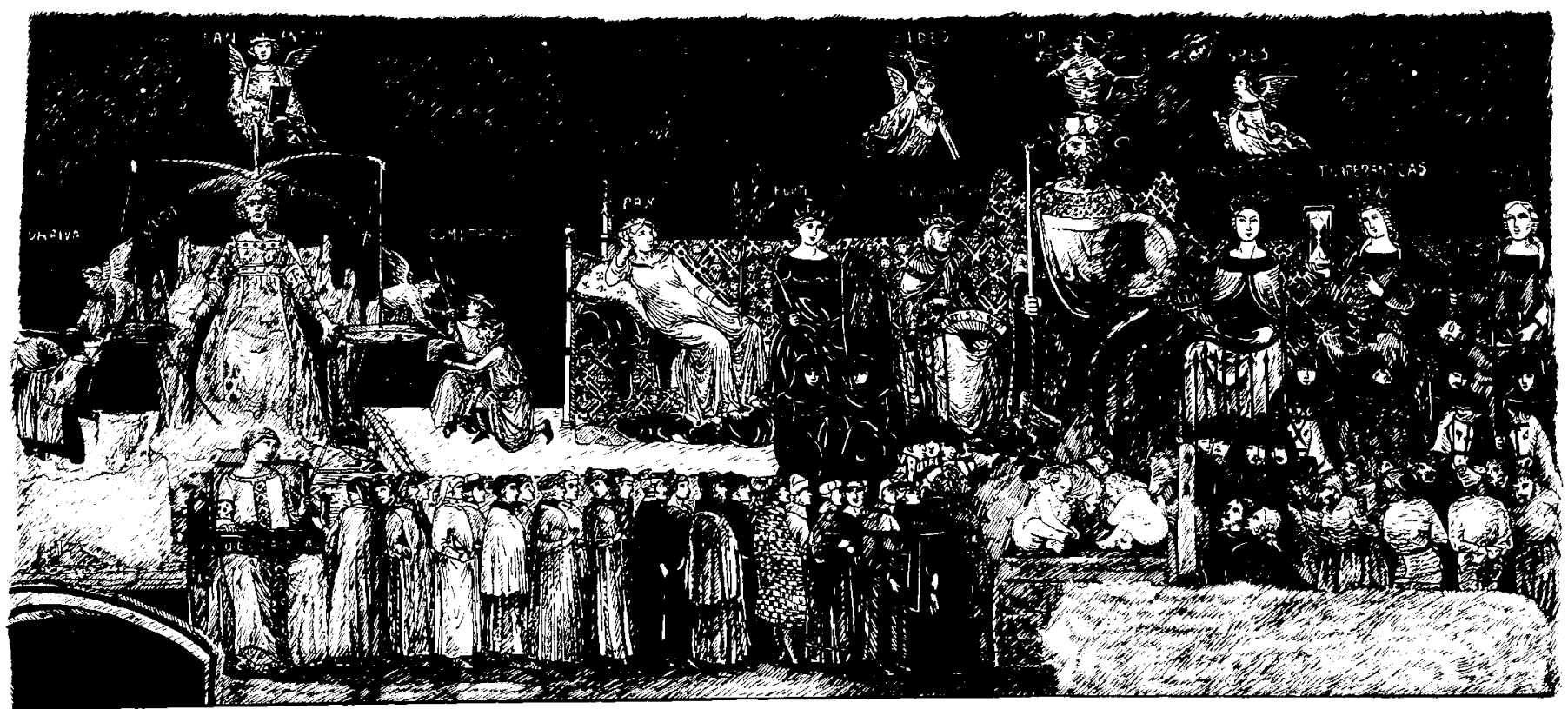

Fig. 2. The Allegory of Good Government, Ambrogio Lorenzetti, Palazzo Pubblico, Siena, Italy, 1338. 


\section{THE COMPARISONS: BUILDING MATERIALS}

Although the prevalent building type and material in Siena is brick, most foundations of the structures are of stone. This symbolizes the nobility and their essential part in the feudal system, social upheavals, and eventual founding of the citystate system. In the 1300 's a conscious decision was made by the governing "Nine" to use brick for the fortified encircling walls and the palazzi structures. Brick work formed of the indigenous clay creates most structures, towers, and piazze. Built by the people with their hands, this act alone connected them spiritually with their city. (Stone construction on the other hand involved large-scale stone quarries, hoists, and devices which separated the people from the actual building process.) The brick theme gives a context both historically and visually to the city, setting its homogeneous character, so that, the architecture of Siena reinforces its oneness and its homogeneity. All buildings within the center are considered historic, treasured, and well maintained for uses consistent with the civic life of the city and province.

Moreover, the well defined city form completely contained by a massive fortified wall "is seen as an entity, as indeed the cities of this period were seen by their citizens, including the builders who changed and enlarged them. It is this image of the totality that is one of the most important contributions of medieval design." 23 During 'the Dark Ages' "the medieval mind took comfort in a universe of sharp definitions, solid wall, and limited views." ${ }^{24}$ The wall as a meeting place between the past and the future, "the urban and the rural, the insider and the outsider;" the peasant and the citizen. It provided a 'sanctity of place' unknown previously. Medieval urbanization originated the civic nucleus, the wall, and the gates, and the wall "made the town an island." 2.5

Los Angeles has grown sporadically over the past 200 years. Each addition to the fabric of the city relates to current technology and building theory. There are represented a wide variety of building types and materials from all over the world. The architecture reinforces the distinctions of life in L.A., expressing disparate preferences, while reflecting the separate histories, cultures, and races of her citizens. Each successive generation of Angelenos has built over the architecture of the last, erasing the traces of the original pueblo, the Victorian boomtown, the garden city. In a rush to validate the advertisements of healthful living, city planners of Los Angeles continually supported the razing of the older structures, equating the old with poverty, the new with prosperity. In contrast to a city built by hand over a long period of time, the civic and institutional Los Angeles, being built in the time of industry and mechanization, has grown swiftly and the builders, owners, and the users have been separated from the act of building.

\section{THE COMPARISONS:}

\section{SOCIAL AND NATURAL PROBLEMS}

Father Juan Crespi, a Spanish missionary and one of the first
Europeans to see the Los Angeles basin, traveled through in August, 1769. Writing in his journal, he noted that the area was beautiful and "a perfect place for a mission settlement." He stayed long enough to notice the signs of alternating drought and "great floods," and felt earthquake after earthquake, "which astonishes us." 26

These threats still exist in Los Angeles today. Earthquakes are becoming more frequent. The fear of drought is offset by the threat of torrential rains and mud slides which follow the resultant fires. The cycle of natural disaster is broken only by the unconscious theory that Angelenos have used to save themselves; that is, designing a city that is distributed in a thin coating over 451 square miles. In a city of density any one of Los Angeles's disasters of nature would have leveled it, but the city exists and continues to exist because it has been dispersed over a vast area in single-story structures.

Decimated by the 1348 Bubonic Plague, Siena "subsequently suffered economic and political eclipse and entered a period of relative obscurity," ${ }^{27}$ surviving intact as essentially one of the most beautiful Gothic towns in Italy. Siena is a city of homogeneous form and character with one city government relating to seventeen contrade within the fortified city walls and the friction which does occur is not based on ethnic or varied cultural differences. Due to the contrade system, which is determined by birth and territory, crime and the effects of drugs have been kept at a minimum. Whereas in Siena, one vision of the homogeneous group mirrors the homogeneous culture, a singular vision in Los Angeles would create ethnic disparity and cultural dissent, a riotous prone atmosphere. The many town and city groupings and the disparity of ethnic groups provide a multiplicity of viewpoints creating an unclear vision for Angelenos.

Currently, Los Angeles is in the midst of a recession affecting all sectors of society. The economy must now absorb the excess of the 1980's, the saturated real estate market, over built commercial interests, loss of government military contracts and mass immigration. But Los Angeles has experienced expansive growth and its deleterious results before. Carey McWilliams described the latter part of the 19 th century and the early part of this century:

The great boom of the "eighties had been spectacular, but it had been limited to land speculation. The boom of the "twenties, on the other hand, was a truly bonanza affair. Millions of dollars in new income poured into Los Angeles, undermining the social structure of the community, warping and twisting its institutions, and ending in a debacle (the stock market crash) .... For Southern California the decade was one long drunken orgy, one protracted debauch. ${ }^{28}$

The 1980's have proven to be another decade of excess. Continuing the myth of prosperity Angelenos have leveled and rebuilt various sectors of the city, creating "a city of erasure, and camouflage." 29 


\section{THE COMPARISONS:}

\section{CIVIC ART + ALLEGORIES OF SOCIAL ETHOS}

The use of the Comune di Siena in a comparative study is invaluable in that "Siena is still to a considerable extent the expression in physical form of the cultural values of the medieval urban mind; the articulation in stone, brick, and marble of a medieval view of the world." ${ }^{30}$ Study of the Comune di Siena versus study of 'the city' implies analysis of the 'collective' governmental body and the ethos involved in "the vita civile, a phrase combining the concepts of civic life and civilization," ${ }^{31}$ not merely the resultant city form and its architecture.

Begun in 1317, the most comprehensive example of didactic civic art is Ambrogio Lorenzetti's set of frescoes now known as, The Allegory of Good and Bad Government which can still be viewed in situ in the Sala della Pace in the Palazzo Pubblico in Siena. Covering three walls of the Salon of Peace, so named for one of the major figures in the compositions, it visually symbolizes, in the very heart of the regime, the Sienese civil attitudes and beliefs regarding government. Originally, simply called Peace and War, ${ }^{32}$ these magnificent allegorical works "constitute the most important remaining secular decorative scheme from the Europe of their time," ${ }^{33}$ and record the effects of both good and bad government on the city and on the countryside. Undoubtedly developed and "meant to serve political and didactic purposes, ${ }^{34}$ Lorenzetti used the overall structures and atmosphere of Siena to express "the whole wealth of Medieval learning," ${ }^{35}$ by integrating the virtues and values of Augustinian and Thomist thought in a universal naturalistic manner. "Replete with classical allusions, they run the gamut from meticulous allegorical expressions of contemporary political ideals and realities to town and landscape panoramas so revolutionary that there is not the remotest contemporary parallel anywhere else." ${ }^{36}$

. The primary object of all medieval painting was didactic. The Allegories were "designed for the eyes of the ruling_lite of the city." ${ }^{37}$ Inscriptions placed throughout the work which clarify the complex allegorical intent, were statements directed to "the obligations of the governor to the governed, rather than about the obligations of the governed to the governing." ${ }^{38}$ These themes were externalized for all citizens in sculptural art in other civic projects.

While Lorenzetti presented "a Summa of all contemporary knowledge about political life," 39 it was not couched in any city; the palaces, the houses, the streets, and countryside, were all Sienese. Moreover, "Siena and its life [were] used to define the concept of the city." ${ }^{40}$ Lorenzetti clearly depicted Siena as 'Heaven,' the City of God, Jerusalem, the Civitas Dei of this world. This prototype "for the perfect civilized life, had become conflated in the Sienese imagination, and this conflation has ever since remained a central feature of Sienese cultural life." ${ }^{\text {41 }}$ This is evidenced, for instance, in their continued stewardship of 'the city' as well as in their belief that the best Italian language is spoken only in Siena.

Notable cultural historian, John Larner commences his scholarly work Culture and Society in Italy $1290-1420$ by crediting Lorenzetti with being the first to "clearly refer to the relation between culture and society." 42 Succinctly put, "The allegorical meaning of the painting is that the civilization of the city was dependent upon a particular society and its just and ordered government." ${ }^{43}$

Los Angeles, in the heady days and years before the Great Depression, decided to create a monument to their own democratic city government, and to "build a building which would set an example for governmental buildings all over the world." ${ }^{44}$ The movement in 1926 in American architecture as exemplified in the construction of the new Los Angeles City Hall was to "express . . . the purpose of the building." 45 Whether in the building forms or in the decorative treatment, more functional civic buildings were being designed for the use of the public. With this modern functionalism came realization for the need to enrich the simplistic forms. Permanent materials such as various "natural and unique" marbles and tile were used as surface treatments "so placed as to give color and richness." 46

Whereas Siena's magnificent Palazzo Pubblico, Town Hall, was constructed over decades, with major portions completed by $1284,1298,1305$, and $1310,{ }^{47}$ it maintained a clear rigor of singular expression becoming one of the finest secularGothic buildings ever built. Conversely, Los Angeles's turriform ${ }^{48}$ City Hall, with an airway beacon on its pyramidal conclusion, was conceived and built in only a few years time yet it was composed of three different styles of architecture in a conglomerate structure. "Grecian detail was adopted for the main entrance, while Romanesque was used in the arcades of the Forecourt, Rotunda, Council Chamber and the Board of Public Works Session Room. The tower and the flanking wings may be regarded as "modern American." 49

To further memorialize the past and to instill importance in the building, decorative treatments of historicized figures in a Byzantine style were used to commemorate significant events in the founding of Los Angeles. "The various attributes of municipal government" are evidenced in the Rotunda. "The domed ceiling, pendentives and barrel vaults

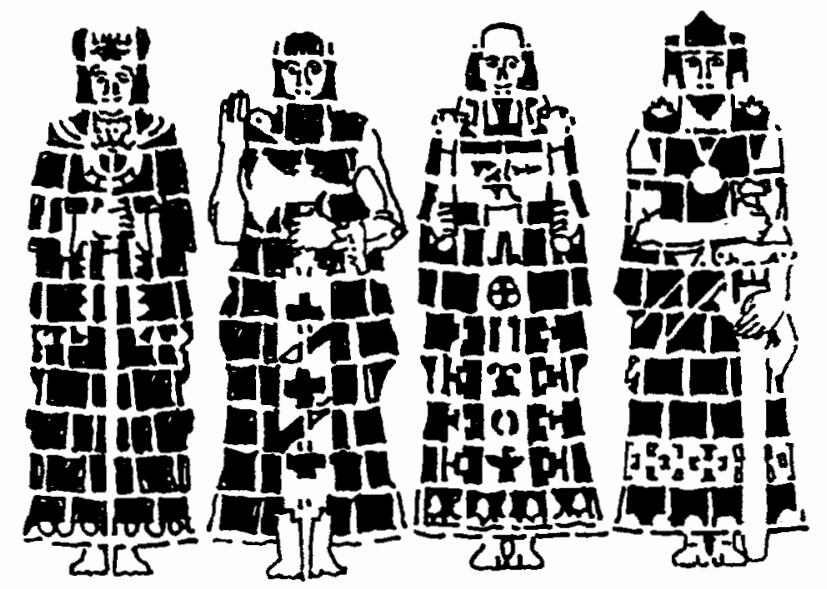

Fig. 3. Detail, Rotunda in Los Angeles City Hall, 1928, Government, Law, Education, Protection. 
are inlaid" with faience tile arranged in a highly decorative manner, with figures symbolizing "Art, Public Service, Government, Protection, Trust, Education, Health, and Law." Barrel vaults which pierce the dome, "are decorated to represent Justice, Government, and the city's patron saint, Our Lady, Queen of the Angels." 50

The civic art of Siena was the major focus wherever it was placed, in fact, it was selectively placed in commanding locations. The Allegory of Good Government panel, for example is placed in the Salon of Peace so that it receives the full light of the sun, from the only window in the room. The Effects of Good Government receives the next best light, and the Allegory and Effects of Bad Government the least. The content in this civic art reflects the reason and wisdom, the depth of human philosophy and knowledge at that point in history. Even today, Lorenzetti's frescoes "emphasize the remoteness of an age and a world we no longer share," bringing to us still in a "tantalizing effect, seeming both to resurrect medieval Siena, to make it tangible and populated with familiar figures, and paradoxically," aware of its distance in time and place.

The art work in the L.A. City Hall was confined to an additive process and was used to define the edges of struc-

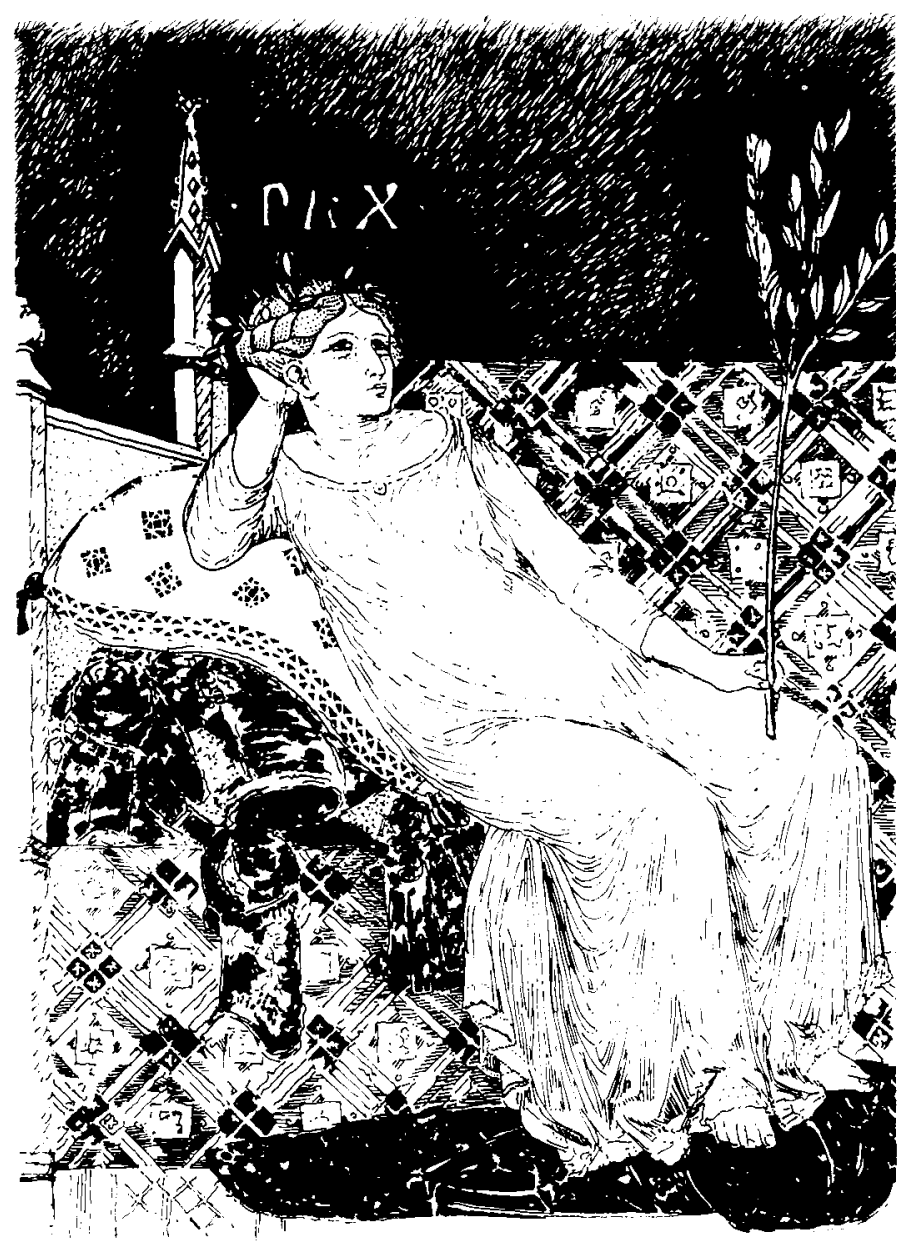

Fig. 4. Detail of the Allegory for Peace, Ambrogio Lorenzetti, Palazzo Pubblico, Siena, Italy, 1338. ture, the walls of arcaded passages, to fill the void of the dome and the barrel vaults. In other words, the art was used as a decorative surface, not as the major substance or focus of a space, such as the figure which commemorates peace in the Salon of Peace in Siena. The subject matter dealt with the matters important to the fledging town. For instance, all of the City's important industries were depicted along arcaded passages, and are modeled in bas relief: Motion Picture, Machinery, Automotive, Oil Production, Building, Shipping, Airplanes, and Printing. Doors of bronze commemorate simple events in the history of the city.

The Allegory provides for the citizens of Siena a sense of identity with the city itself. "What sense of identity does the citizen have when the city he lives in is without a significant image? ... it is a matter of giving to the individual the basic ontological security of knowing where he is in Life." 52 The civic art as represented in the L.A. City Hall are caricatures without a place in the city. The figures are not grounded on a plane or in an architectural sense, and there is no artistic image of the city in the murals. Los Angeles in building its City Hall accepted the separation that had occurred between the reality of the city and the city's image with its choice to depict its history and attributes as unconnected to an image of the city.

\section{CONCLUSION}

Through study of the differences and similarities of the historic center of Siena and the modern metropolis of Los Angeles, parallels and conclusions have been drawn. Looking in hindsight at decisions which affected the urban plan of Siena may help Los Angeles in its move into the next century to grow into a place of naturalistic and artistic built beauty, a place of civic pride and historic accomplishment.

It has been especially pertinent to analyze the art and architecture of these two great cities, as "all art, but particularly Architecture, expresses social history." ${ }^{33}$ Siena is exemplar in the discovery of principles basic to a healthful environment that promotes 'happiness,' the progenitor to a vital, vibrant society. The Sienese have chosen historically to elevate their city and civic art to be examples to the rest of the world as "the importance of art as a moral activity remains; beauty still exists to convey the absolute values upon which a sound society must rest; but if the art of a nation is beautiful, it is because its society is noble." ${ }^{54}$

Los Angeles is the city of the moment, dependent upon technology and its mythical image. But caution should be taken by all who interpret cities, as the historian Leonardo Benevolo writes:

Cities still remain specifically historical creations. They have not always existed; they began at a certain period in the evolution of society and can equally be ended or radically transformed at another. They came into being not as a result of any natural necessity, but as the result of an historical need, and they will continue only for as long as this need persists. ${ }^{5 .}$ 
The Sienese legacy, The Allegory of Good and Bad Government, frescoes contrast with civic mural art and the 'vandal' graffiti of Los Angeles illustrating how each reflects the ethos, the attitudes and intrinsic values of each city. This comparison between medieval Siena and modern Los Angeles is a compelling and provocative study intended to define the differences and the similarities between these two great centers of humanity. It is an attempt to clarify those inherent principles and characteristics in order to form guidelines for implementing a revived approach to the design of cities and neighborhoods.

Illustrations: Mark Lloyd Lakeman, Alexandra Maskell, and Karen Figura Lange

\section{NOTES}

1 Elizabeth Moule and Stefanos Polyzoides, "Downtown in the Twentieth Century: The Struggle for Defining the Centre of Los Angeles," World Cities, Los Angeles, (London: Academy Editions, 1994), 29.

2 Judith Hook, Siena, A City and Its History, (London, Hamish Hamilton Limited, 1979), 2.

' Leonardo Benevolo, A History of the City, (Cambridge, Massachusetts, MIT Press, 1981), 253-254.

${ }^{4}$ John Larner, Culture and Society in Italy 1290-1420, (New York, Charles Scribner's Sons, 1971), 63.

${ }^{5}$ Heldner, Jeffrey, "The Writing of Architecture: Mnemosyne and the Wax Tablet," OZ, Volume 12, (College of Architecture \& Design, Kansas State University, Manhattan, Kansas, 1990), 4.

' John Ruskin, The Seven Lamps of Architecture, (London, New York, Cassell and Company Ltd., 1909), 249.

7 Hook, 9.

${ }^{8}$ Father Juan Crespi, diary entry, 1769, Sam Hall Kaplan, LA Lost \& Found, An Architectural History of Los Angeles, (New York Crown Publishers, Inc.), 19.

${ }^{9}$ Charles Jencks, Heteropolis; Los Angeles, The Riots and The Strange Beauty of Hetero Architecture, (London, Academy editions, 1993), 23.

${ }^{10}$ CMSA 1990

1 Elizabeth Moule and Stefanos Polyzoides, "The Five Los Angeleses," World Cities, Los Angeles, (London, Academy Editions, 1994), 11.

12 Carey McWilliams, "Looking for History in LA," Unknown California, Editors, Jonathan Eisan and David Fine, (New York, Macmillan Publishing Company, 1985), 176.

${ }_{13}$ Lewis Mumford, The City in History, Its Origins, Its Transformations, and Its Prospects, (New York, Harcourt, Brace \& World, Inc., 1961), 301.

14 Ibid, 303.

15 Leon Battista Alberti, The Ten Books of Architecture, The 1755 Leoni Edition, (New York, Dover Publications, Inc, 1986), Book IV, Chap. V., 75.

${ }^{16}$ Andrea Brogi and Daniela Gallavotti Cavallero, Lo Spedale Grande di Siena, Fatti urbanistici e architettonifi del Santa Maria della Scala, (Firenze, la casa USHER, 1987), 16-17.

${ }^{17}$ Ibid., 32.

${ }^{18}$ Ibid., 77.

${ }^{19}$ Kim Coleman, "Los Angeles Made Visable," World Cities, Los Angeles, (London, Academy Editions, 1994), 36.
20. Sandra Davis Lakeman, Natural Light and the Italian Piazza, Siena, as a Case Study, (Siena, Alsaba Grafiche, 1992), 90.

${ }^{21}$ Elizabeth Moule and Stefanos Polyzoides, "The Five Los Angeleses," World Cities, Los Angeles, (London, Academy Editions, 1994), 17.

${ }^{22}$ Elizabeth Moule and Stefanos Polyzoides, "Downtown in the Twentieth Century: The Struggle for Defining the Centre of Los Angeles," World Cities, Los Angeles, (London, A.D. Academy Editions, 1994), 33.

${ }^{23}$ Edmund N. Bacon, Design of Cities, (New York, Penguin Books, 1974), 93.

${ }^{24}$ Mumford, The City, 304.

${ }^{25}$ Ibid.

${ }^{26}$ Richard Reeves, "Vulnerable" Unknown California, by Jonathan Eisen and David Fine, (New York, Macmillan Publishing Company, 1985) 167.

${ }^{27}$ Hook, 77.

${ }^{28}$ Carey McWilliams, Southern California: An Island on the Land, in LA Lost \& Found, An Architectural History of Los Angeles, (New York, Crown Publishers, Inc., 1946), 63.

${ }^{29}$ Ibid.

30 Hook, 5-6.

${ }^{31}$ Hook, 2.

${ }^{32}$ Chiara Frugoni, Pietro and Ambrogio Lorenzetti, (Florence, Scala, Istituto Fotografico Editoriale, Antella, 1988), 3.

$33 \mathrm{~J}$. R. Hale, A Concise Encyclopaedia of the Italian Renaissance, (New York and Toronto, Oxford University Press, 1981), 192.

${ }^{34}$ Nicolai Rubenstein, Political Ideas in Sienese Art: The Frescoes by Ambrogio Lorenzetti and Taddeo di Bartolo in the Palazzo Pubblico, (London, Journal of the Warburg and Courtauld Institutes, University of London, 1940), 179.

${ }^{35}$ Hook, 91.

${ }^{36}$ Hale, 192.

${ }^{37}$ Hook, 83.

${ }^{38}$ Ibid.

${ }^{39}$ Ibid., 91.

40 Ibid.

41 Ibid., 92,

42 Larner, 9-10.

43 Ibid.

${ }^{44}$ John Gregory Dunne, "Eureka! A Celebration of California," Unknown California, Editors Jonathan Eisen and David Fine, (New York, Macmillan Publishing Company, 1985), 20-21.

${ }_{45}$ Faith Holmes Hyers, The New Los Angeles Library, (Chicago, Library Bureau, 1926), 74

${ }^{46}$ Frederick Jennings, "Los Angeles City Hall," The Architect and Engineer, Vol. 93, No. 2, May, 1928, (San Francisco, The Architect and Engineer, 1928), 35.

47 Aldo Cairola and Enzo Carli, The "Palazzo Pubblico" of Siena, (Roma, Editalia for Monte dei Paschi di Siena, 1964), 30.

48 E.A. Fisher, Anglo-Saxon Towers, an Architectural and Historical Study, (Great Britain, David \& Charles Limited, 1969), 15. [It infers a tower-building, not a building with a tower.]

${ }^{49}$ George P. Hales, Los Angeles City Hall, (Los Angeles, California, Times-Mirror Printing and Binding House, 1928), 14.

${ }^{50}$ Ibid., 33.

sl Hook, 1.

52 William Irwin Thompson, "Looking for History in L.A." Unknown California, Editors, Jonathan Eisen and David Fine, (New York, Macmillan Publishing Company, 1985), 179.

53 Hewison, 130.

54 Ibid., 133.

55 Benevolo, 5. 